\title{
MEF2C Gene
}

National Cancer Institute

\section{Source}

National Cancer Institute. MEF2C Gene. NCI Thesaurus. Code C92161.

This gene plays a role in muscular and vascular development. 